and is found throughout the North American ranges of deer, Elk and Moose except the far north. Deer and Elk seem able to co-exist with this parasite, and they remove most of the ticks by efficient grooming before they can do much harm. But Moose are less capable of combating an infestation. The eggs of D. albipictus are laid on vegetation in the spring, and from September to November the hatched larvae climb up the vegetation and attach themselves to a passing animal. After November the larvae left on the ground die. Once attached to Moose, larvae feed on Moose blood before becoming nymphs; the nymphs are dormant until February, then moult and become adult ticks. All three stages depend on blood to survive, but it is in March and April that their feeding causes the Moose to become so weakened by loss of blood that some can die. The tick bites can also introduce other pathogens into the host so that there may be multiple causes for death. After May, the female ticks drop off the host, lay their eggs in sheltered places and the cycle starts again. The irritation of the bites make the Moose groom incessantly, mostly with its tongue, which breaks off the ends of the coat hair leaving only the short undercoat exposed. This is grey-white and gives the Moose the typical "ghost" appearance. Licking can also break the skin, allowing easier access for the ticks. A serious infestation will create large open areas of bleeding skin and consequent debilitation.

Moose populations in Canada are stable, but when a local population increases, the young in particular start the winter under-nourished and more susceptible to disease. Then there can be a serious die-off in
March and April due to tick infestation. There were major die-offs of up to $50 \%$ of the population in some areas in 1991 (Minnesota), 1999 (six provinces, British Columbia the worst), and 2002 (eastern provinces and the prairies). Some dead Moose have carried more than 500000 ticks. Effective prevention is difficult but Dr. Samuel suggests that a possible solution would be to cull Moose where there is a population build up, thus reducing the demand on the available food sources. Experiments have shown that Moose can detect and avoid tick-infested vegetation but if food is scarce, they will eat it.

There are chapters on the life cycle of the tick, how they are adapted to attack Moose, their invasive characteristics and behavioural strategies used by Moose to evade the ticks. The book is attractively illustrated and for light relief, there are good puns on the word "tick": e.g., characteris-ticks, and a poem or two. Knowing more about the life cycle of the tick and its serious effects on Moose populations should be of value to anyone travelling or working in the areas where moose are found.

The Federation of Alberta Naturalists has published several natural history books, and their Atlas of Breeding Birds of Alberta is a best seller. They commissioned Dr. Samuel to write Ghost Moose which is an interesting and serious book about a wildlife disease. It makes absorbing reading and describes an aspect of wildlife we seldom hear about.

JANE ATKInSON

255 Malcolm Circle, Dorval, Quebec H9S 1T6 Canada

\title{
Lewis and Clark on the Great Plains: A Natural History
}

By Paul A. Johnsgard. Bison Books, University of Nebraska Press, 1111 Lincoln Mall, Lincoln, Nebraska 68588-0630 USA. 143 pages, $\$ 18.28$.

One of the most profound expeditions in American history and culture was of the Lewis and Clark adventures, 1803-1806. Led by Meriwether Lewis (17741809) and William Clark (1770-1838), the expedition was one of the first systematic surveys of the natural resources and natural history of the American west. And as such, the published record since the early $19^{\text {th }}$ century pertaining to these treks is voluminous. From narratives and journals (e.g., Moulton 1983-2002), their place in history, and their experiences with natural history (Cutright 1969), all raise Lewis and Clark to American cultural icons.

Johnsgard's Lewis and Clark on the Great Plains adds to this list but should not be considered a significant contribution to the histrionics of the expedition and what it meant. The author's contribution is more in line with a combination field guide / history lesson of the wildlife encountered by Lewis and Clark's group. Following a brief introduction, the book is chaptered by contemporary States with regional maps outlining expeditionary routes. This template is essential in un- derstanding the chronology as the expedition at times retraced their steps in a single season, if not over the course of the expedition's history.

The bulk of the content is a listing of the flora and fauna (complimented with scientific and common names). In user friendly manner Johnsgard provides a concise synopsis of the taxa followed by shorter notations as to the encounters with the expeditionary force. The Western Hognose Snake (Heterodon nasicus) for example, was likely found and described on July 23, 1805 near Townsend, Montana, prior to the formal erection of the species in 1852 (Baird and Girard 1852). Based on his description, "Lewis should be credited" Johnsgard contends, "with the discovery of the species" (page 97).

Visual support for the descriptions come from the authors own line drawings, 39 in all. Simple in vision yet detailed, collectively with the body of text, make this little volume an added historical perspective to viewing nature as it once was, 200 years ago.

\section{References:}

Baird, S. F., and C. F. Girard. 1852. Reptiles. Pages 336-353 in Exploration and Survey of the Valley of the Great Salt Lake of Utah, including a reconnaissance of a new rout through the Rocky 
Mountains. Edited by H. Stansbury. Lippencott, Grambo, and Company, Philadelphia, 487 pages.

Moulton, G. E. Editor. 1983-2001. The Journals of Lewis and Clark Expedition. 13 volumes. University of Nebraska Press, Lincoln.

\section{Waterfowl of Eastern North America}

By Chris G. Earley. 2005. Firefly Books: Buffalo, New York; and 3680 Victoria Park Avenue, Toronto, Ontario M2H 3K1 Canada. 158 pages. $\$ 19.95$ Paper.

This attractive bird identification book is clearly aimed at the beginner birder. It is the fourth in a series of similar books by the same author and publisher. Earley properly cautions new birders about hasty and uncertain judgments in the often perplexing task of bird identification.

A cursory review of this handsomely printed, fullcolor book, measuring $5 \frac{1}{2} "(14.0 \mathrm{~cm})$ by $8 \frac{1}{2} "(21.6 \mathrm{~cm})$ by $1 / 2 "(1.3 \mathrm{~cm})$, makes a favorable first impression. In particular, the photographs of individual birds, usually in nuptial plumage, on the water and flying, and when used in comparison with look-alike birds, are excellent. Two pages are usually devoted to each species, including photographs, a small range map, and brief text mostly descriptive of non-breeding season plumages. Two to four sentences tell a bit about each species and a sentence or two under "Nature Notes" provides additional eclectic, often trivial information.

Unfortunately, my initial favorable impressions soon changed. First, the title is a misnomer. A substantial number of the species included are not waterfowl as defined by the AOU checklist, which the author references. Rather, the author re-defines waterfowl to include other "ducklike birds", such as some species of loons, grebes, pelicans, cormorants, rails, and gallinules. Attention to these species comprises about a quarter of the pages accorded the true waterfowl.

North America and Eastern North America are not defined. By AOU definition the mainland of North America extends south through Panama, including associated islands. Consequently, some native North American species are missing. On the other hand, several exotic or species of rare or irregular occurrence are addressed (e.g., Mute Swan, Barnacle Goose, Garganey, Tufted Duck, and Smew). Oddly, four full pages are devoted to each of three species rarely (unlikely ever to be) seen by many birders (the King and Common eiders and the Long-tailed Duck); but the commonest North American duck, the Mallard, receives only two pages.

Other problems arise. The range maps are too small, especially for coastal species when the pale yellow representing winter range is cast against the light gray background. The map depicting the wintering range of the Blue-winged Teal (page 47) as including northeastern Argentina, Paraguay, Uraguay and extreme southern Brazil is incorrect. Upon close examination,
Cutright, P. R. 1969 [1989]. Lewis and Clark: Pioneering Naturalists. [Reprint]. University of Nebraska Press, Lincoln.

TIM TOKARYK

Box 163, Eastend, Saskatchewan S0N 0T0 Canada

the unnatural, vertically-flying shoveler (page 9) is certainly a cropped view of the horizontally-flying bird depicted on page 14 with the photo reversed and rotated 90 degrees. The photograph of a flying male Common Merganser (page 147) is mis-labeled as a Hooded Merganser.

The two-page chart titled "Seasonal Status of Waterfowl" (pages 16-17) is based solely on observations at Point Pelee National Park [Ontario]. While perhaps useful in showing relative species abundance and temporal distribution in the Great Lakes region, it has questionable relevance elsewhere.

"What can I do to help waterfowl?" (pages 130131). is largely about nesting boxes. Only a half-dozen or so waterfowl utilize such structures. Nothing is said about North American waterfowl being protected by international treaties, federal laws, and laws and regulations of the various states and provinces.

The list of references (pages 154-155) is peculiar. Some entries are outdated (e.g., Studer, 1881) or are primarily of works of art (e.g., Brasher 1962, Lansdowne 1980). While the definitive AOU The Birds of North America monographs (Poole and Gill, eds.) are noted, their scientific excellence, content, and format are undescribed and their general unavailability, except in larger libraries, is unmentioned.

A number of important waterfowl references are overlooked (e.g., Delacour's four-volume The Waterfowl of the World; Palmer's Handbook of North American Birds, Volumes 2 and 3, Waterfowl; Volume 1 (Ostrich to Ducks) of the magnificent Handbook of the Birds of the World, edited by del Hoyo, Elliott, and Sargatal; and even the early but enduring John C. Phillips' four-volume opus, A Natural History of the Ducks. Despite the attention given wood ducks and nesting boxes, Frank Bellrose's splendid monograph (Ecology and Management of the Wood Duck) is likewise missing. All of these basic references could easily have been accommodated in the large blank space on page 155 .

Much of what the novice birder learns in this book will have to be forgotten should his early interest in birding lead him forward. Perhaps the concerns and errors noted above, and others unexpressed, will be corrected in a reprinting. In the meantime one would be wiser to spend a few more dollars for one of several time-tested, authoritative field guides listed among the author's references.

HENRY M. REEVES

22250 Boulder Crest Lane SE, Amity, Oregon 97101 USA 